\title{
Sınıf Eğitimi Bilim Dalı'nda Çocuk Edebiyatı Konulu Lisansüstü Çalışmalara Genel Bakış: Bir Meta-Sentez Çalışması
}

DOI: $10.26466 /$ opus. 888446

\author{
Hülya Kodan * - Kürșad Kara ** \\ * Dr. Öğr. Üyesi, Bayburt Üniversitesi, Eğitim Fakültesi, Bayburt/Türkiye \\ E-Posta: hulyakodan@bayburt.edu.tr \\ ORCID: $\quad$ 0000-0002-4681-5972 \\ ** Dr. Öğr. Üyesi, Bayburt Üniversitesi, Eğitim Fakültesi, Bayburt/Türkiye \\ E-Posta: kkara@bayburt.edu.tr \\ ORCID: $\quad \underline{0000-0002-8190-5180}$
}

\section{Öz}

Bu çalışmada Sınıf Eğitimi bilim dalında çocuk edebiyatıyla ilgili lisansüstü çalışmalardaki eğilimleri ortaya koymak amaçlanmıştır. Bu amaç doğrultusunda meta-sentez yöntemi kullamılmıştır. Nitel verilerin yorumlanması ve değerlendirilmesi temel alınmış, incelenen çalışmalar nitel bir yaklaşımla ele alınarak sonuçlar derinlemesine irdelenmiş, benzerlik ve farklllıklar ortaya konulmuştur. Verilerin toplanmasında Yükseköğretim (YÖK) Ulusal Tez Merkezi veri tabanından faydalanılmıştır. Araştırmaya 2010-2020 yılları arasında gerçekleştirilmiş olan 31 yüksek lisans, 1 doktora olmak üzere 32 tez dâhil edilmiştir. Araştırmanın yöntemi kapsamında süreç ve bulgular detaylı bir şekilde rapor edilmiştir. Araştırma sonucunda; çalışmaların çoğunluğunun konu alanı itibariyle kitap/metin incelemesi altında değerler eğitimi ile ilgili olduğu, doküman incelemesi yöntemi üzerine yoğunlaştı̆̆l, veri analizinde içerik ve betimsel analizin sıklıkla kullanıldı̆̆ı görülmüştür. Çalışmaların geçerlilik ve güvenirliklerinin sağlanmasında yoğunlukla doğrudan alıntı ve uzman görüşüne başvurulduğu, çalışmaların çoğunluğunun hikâye/kitap incelemesi/değerlendirilmesine yönelik sonuçlar sunduğu belirlenmiştir. Çalışmaların sonuçlarına yönelik önerilere ilişkin verilerde ise çocuk edebiyatı ürünlerinin içeriğine yöneliköneriler ön plana çıkmıştır. Öğretmen, ebeveyn ve eğitimcilerin çocuk kitaplarn ile ilgili farkındalık kazanmasına yönelik öneriler de yer almıştır.

Anahtar Kelimeler: Sınıf eğitimi, çocuk edebiyatı, meta-sentez. 


\title{
Overview of Graduate Studies on Children's Literature in the Science of Classroom Education: A Meta-Synthesis Study
}

$*$

\begin{abstract}
In this study, it is aimed to reveal the trends in postgraduate studies related to children's literature in Classroom Education. For this purpose, the meta-synthesis method has been used. The interpretation and evaluation of qualitative data were taken as a basis, the studies examined were handled with a qualitative approach, the results were examined in depth, similarities and differences were revealed. Higher Education (YÖK) National Thesis Center database was used to collect the data. 32 theses including 31 masters and 1 doctorate, which were carried out between 2010 and 2020, were included in the research. The process and findings were reported in detail within the scope of the research method. As a result of the research; It was observed that most of the studies were about values education under book/text analysis in terms of subject area, focused on the method of document analysis, and content and descriptive analysis were frequently used in data analysis. It was determined that direct quotations and expert opinions were frequently used to ensure the validity and reliability of the studies, and the majority of the studies provided results for story/book review/evaluation. In the data regarding the suggestions for the results of the studies, suggestions for the content of children's literature products came to the fore. There were also suggestions for teachers, parents and educators to raise awareness about children's books.
\end{abstract}

Key Words: Classroom education, children's literature, meta-synthesis. 


\section{Giriş}

Dil gelişimine yardımcı olan temel dil becerilerinden biri okuma eylemidir. Özellikle okul öncesi, sınıf ve Türkçe öğretmenlerinin sınıf içi çalışmalarında kullanacakları nitelikli metinlerin dilin gelişimine de katkı sağlayacağ 1 düşünülmektedir. Özenle seçilen metinler Aytaş'a (2003) göre okumayı öğrenmek için çocukluk döneminde gerekli yeteneğin elde edilmesi için önemlidir. Bu dönemde öğrencinin hazır bulunuşluğunun yanı sıra okumaya karşı istekliliği de önemlidir. Demircan (2008) çocuğun erken yaşlarda okuma alışkanlığını kazanabilmesi için de çocuğa özgü eserlerin hazırlanması gerektiğini dile getirir. Öğrencilerin dil gelişimlerinin ve okuma alışkanlıklarının kazanımı ve gelişimi için eğitimcilerin yöneleceği adreslerden biri çocuk edebiyatıdır.

Çocuk edebiyatı, erken çocukluk dönemi ile ergenlik dönemi arasındaki yaşam döneminde, kurmaca dünyalar yoluyla çocukların anlama seviyeleri ve dil gelişimlerine uygun bir biçimde hazırlanmış, duygu, düşünce ve hayal dünyalarını zenginleştiren, ruhsal gelişimini destekleyen dilsel ve görsel ürünlerin tamamına verilen isimdir (Oğuzkan, 1983, s.12; Sever, 2012, s.27; Balta, 2019, s.466). Diğer bir açıdan çocuk edebiyatı, çocukların psikolojik ve bedensel gelişimlerine uyumlu, çocuğun analiz ve sentez yapmasına imkân tanıyan, çocuğa okuma alışkanlığı kazandıran, sanat ve estetik yönünden gelişmesine katkı sağlayan sözlü ve yazılı edebi ürünlerin tamamı olarak tanımlanmaktadır (Yalçın ve Aytaç, 2005, s.1617; Şirin, 2016, s.24).

Çocuk edebiyatının çocuğun gelişimindeki temel işlevleri yerine getirebilmesinde kitapların çocuğa görelik ilkesini, çocuksu duyarlılığ 1 ve çocuk gerçekliliğini barındırması önemlidir. (Çiftçi, 2013, s.126; Sever, 2013; Şirin, 2016, s.26; Çer, 2019, s.2; Sevim, 2020, s.125). Bu açıdan yaklaşıldığında özellikle çocuğa görelik ilkesi, çocuk edebiyatı ürünlerinin barındırması gereken en önemli ilkelerdendir. Bu kavram; edebi metinlerin çocuğun hayal gücüne yönelik, çocuğun düzeyine uygun anlatım gücüne sahip, çocuğu duygu ve düşünce bakımından gelişimini destekleyen ve işledikleri konu itibariyle çocuğun ilgisini çeken metin özelliği taşıması anlamına gelmektedir (Turan ve Gerez Taşgın, 2018, s.234; Çer, 2016, s.86). Ayrıca bu edebiyat eserlerinin estetik bir boyut taşıması, çocuğun kelime 
hazinesine uygun, ana dilini geliştirebilecek ve anadilinin güzelliğini duyumsatan özellikte olması, milli ve evrensel değerleri içermesi, psiko-sosyal gelişimine katkı sağlaması da gerekmektedir (Temizyürek, 2003, s.161; Turan, 2005, s.128).

Çocuk edebiyatının işlevlerinin etkin bir biçimde yerine getirebilmesi için çocuklarla buluşturulan kitapların onların düzeyine, ilgilerine, gereksinimlerine ve isteklerine uygun olması gerekir (Karagül, 2019, s. 336). Bu kitapların dış yapı özellikleri; büyüklük, kâğıt, kapak-cilt, sayfa düzeni, harfler, vb., iç yapı özellikleri; karakter, konu, ileti, dil ve anlatım ve eğitim ilkeleri yönünden uyum içinde olması gerekir. Çünkü Sever (2006), çocuk kitaplarının biçimsel ve içerik özelliklerinin birbirini bütünlemesi, bazı eğitim ilkelerini kuşatması, kitabı çocuk edebiyatı yapıtına dönüştüren bir özellik olduğunu belirtmektedir. Bu özelliklerin bireyin gelişim düzeyi doğrultusunda dikkate alınması, çocuğa görelik açısından büyük önem arz eder (Baş, 2010, s.157). Çocuk edebiyatı alanında yazılmış nitelikli kitapların edebî ve pedagojik gereksinimlerinin belirlenerek hem işlevsel hem de estetik metinlerin ortaya konması, derinlemesine akademik çalışmaların sonucunda mümkündür (Yazıc1, 2013, s.441).

Türkiye'de sınıf eğitimi alanında çocuk edebiyatı konulu çok sayıda lisansüstü çalışma yapılmıştır. Fakat çalışmaları inceleyen sınırlı sayıda; yüksek lisans tezi (Atalay Yakar, 2012), makale (Balcı, 2012; Balta, 2019; Sevim, 2020; Şahin ve Toprak, 2021; Yazıc1, 2013) ve sempozyum bildirisi (Beyazıt, 2011; Tiryaki, 2016) olduğu görülmüştür.

Mevcut yüksek lisans çalışmasında Atalay Yakar (2019), 1974-2018 yılları arasında Türkiye' de çocuk edebiyatı alanında yapılan lisansüstü çalışmaların konu ve yöntem eğilimlerini incelemiştir. Araştırma nitel araştırma yöntemlerinden doküman inceleme modelinde tasarlanmıştır.

Konu ile ilgili makaleler incelendiğinde Balcı (2012), 1981-2010 yılları arasında çocuk edebiyatı konusunda hazırlanan lisansüstü tezlerini; yıl ve türlerine (yüksek lisans/doktora), hazırlandığ 1 enstitülere, konularına göre sinıflandırarak değerlendirmiştir. Bu araştırmada meta-analiz yöntemi kullanılmıştır. Balta (2019), makalesinde Türkiye'de çocuk edebiyatı üzerine hazırlanan lisansüstü tezlerle ilgili bir meta-analiz çalışması yapmıştır. Çalışmalar; yıl, üniversite, enstitü, bilim dalı, yazıldı̆̆ı dil, konu, konu alınan yazar/şair/çocuk edebiyatçısı, incelenen tema, kullanılan yön- 
tem, veri kaynakları, veri analiz teknikleri bağlamında incelemiştir. Araştırmacı çalışmasını 2011-2018 yılları ile sınırlamıştır. Tezler betimsel içerik analizi ile değerlendirilmiştir. Çocuk edebiyatıyla ilgili lisansüstü çalışmalardaki eğilimlerin neler olduğunu ortaya koyan Sevim (2020) araştırmasında içerik analizi yöntemi, verilerin toplanmasında ise doküman incelemesi tekniği kullanmıştır. Araştırma 1987-2020 yılları ile sınırlandırılmıştır. Araştırmada lisansüstü çalışmaların; yayınlandıkları üniversitelere, yıllara, lisansüstü düzeylerine (yüksek lisans/doktora), araştırma türlerine ve konuları ele alış biçimlerine göre bulgulara ulaşılmıştır. Ayrıca çalışmalara konu olmuş yazarlar, çalışmalarda ele alınan dergi ve gazeteler, ele alınan konu başlıkları, en fazla kullanılan anahtar kavramlar da tespit edilmiştir. Şahin ve Toprak (2021), ilkokul düzeyinde çocuk edebiyatına ilişkin yapılan lisansüstü çalışmaları ve bu konu ile ilgili 10 makaleyi incelemişlerdir. Araştırma 2006-2020 yılları ile sınırlandırılmıştır. Tezler doküman incelemesi tekniği ile incelenmiştir. Çalışmada tezlerin; tez türüne ve yazım yıllarına, yapıldıkları üniversitelere, konularına, konuların coğrafi bölgelere, konu edindiği edebi türe, konu alınan yazara/şaire, yöntemine, veri toplama araçlarına, veri analiz tekniklerine göre dağılımı incelenmiştir. Son olarak Yazıcı (2013), çocuk edebiyatının lisansüstü çalışmalara hangi içerik ve yönelimle konu edildiğini ve bu alandaki araştırmaların eğilimlerini ortaya koymuştur. Buna ek olarak tezlerin konusu, tezlerin ele aldıkları konuya hangi açıyla yaklaştıkları, tezlerin belirli bir dönem ya da tür üzerinde yazılıp yazılmadığı gibi başlıklara ait bulgulara ulaşılmıştır.

Konu ile ilgili sempozyum bildirilerinde ise Bayazit (2011), Türkiye'de 2010 yılı sonuna kadar "çocuk edebiyatı" alanında tamamlanmış tezleri incelemiştir. Çalışmada elde edilen veriler betimsel istatistik teknikleri ile çözümlenmiştir. Tarama modelinde desenlenen bu çalışmada tezler, üniversitelere, enstitülere, yapılış yıllarına, lisansüstü düzeylerine, araştırmacıların cinsiyetine, danışmanların unvanına, konulara, kullanılan araştırma teknikleri ve veri toplama araçlarına göre gruplandırılarak incelenmiştir. Tiryaki (2016) ise, 2011-2016 yılları arasında yazılan çocuk edebiyatı alanındaki lisansüstü tezleri okuma yazma kültürü açısından değerlendirmiştir. Bildiride içerik analizi yöntemi kullanılmıştır. İncelemeye dair kodlamalar; yıl, tez türü, ana bilim dalı, dil becerileri, hedef kitle, çocuk edebiyatı türleri, kategorilerinde gerçekleşmiştir. 
Çocuk edebiyatı ile ilgili lisansüstü çalışmaların incelendiği tez, makaleler ve bildirilere bakıldığında sadece nitel verilerin ele alındığ 1 ve metasentez yönteminin kullanıldığı bir araştırmaya rastlanılmamıştır. Sınıf eğitimi bilim dalı ile sınırlandırılmış tek bir çalışmanın olduğu (Şahin ve Toprak, 2021) tespit edilmiştir. Bu çalışmada sadece üç değiş̧enin ortak olduğu görülmüş fakat bu değişkenlerin ele alınışındaki yöntemin farkl1lığından dolayı mevcut araştırmanın özgün olduğu düşünülmektedir. Çocuk edebiyatı alanında yayınlanmış tezler incelendiğinde, çalışmaların farklı anabilim dallarında yapıldığı görülmüştür. Özellikle de temel eğitim seviyesindeki öğrencilerin okuma becerilerinin gelişmesinde katkısı büyük olan çocuk edebiyatı ile ilgili verilerin tespiti daha önceki yapılan çalışmalarda görülmemiştir. Bu bağlamda, araştırma hem okuma alışkanlığının kazandırılmasının ve geliştirilmesinin ön planda olduğu ilkokul dönemi için, hem Türkçe öğretimine kaynaklık edeceği hem de Sınıf Eğitimi bilim dalında yapılacak araştırmalar için rehberlik edeceği öngörülmektedir.

Bu kapsamda araştırmada Sınıf Eğitimi bilim dalında çocuk edebiyatı konulu lisansüstü çalışmalara ilişkin eğilimleri ortaya koymak amaçlanmıştır. Bu amaç doğrultusunda araştırmanın temel problemi "Sınıf Eğitimi bilim dalında çocuk edebiyatı konulu lisansüstü çalı̧̧maların mevcut durumu nasıldır?" sorusuyla ifade edilmiştir. Araştırmanın temel problemi çerçevesinde cevap aranacak alt problemler şu şekildedir:

- $\quad$ Sınıf Eğitimi bilim dalında çocuk edebiyatı konulu lisansüstü çalışmaların konu alanlarına göre dağılımları nasıldır?

- $\quad$ Sınıf Eğitimi bilim dalında çocuk edebiyatı konulu lisansüstü çalışmalarda kullanılan yöntemlerin (araştırma deseni, çalışma grubu seçimi, veri toplama araçları) dağılımları nasıldır?

- $\quad$ Sınıf Eğitimi bilim dalında çocuk edebiyatı konulu lisansüstü çalişmaların veri analiz süreçlerine göre (veri analiz yöntemleri, geçerlilik ve güvenirlik çalışmaları) dağılımları nasıldır?

- $\quad$ Sınıf Eğitimi bilim dalında çocuk edebiyatı konulu lisansüstü çalışmaların ortaya çıkan sonuçlarına göre dağılımları nasıldır?

- S Sınıf Eğitimi bilim dalında çocuk edebiyatı konulu lisansüstü çalışmaların sonuçlarına yönelik ortaya konan önerilerin dağılımları nasıldir? 
Araştırmanın Sınırlılıkları: Araştırma Türkiye'de Sınıf Eğitimi bilim dalında yapılmış çocuk edebiyatı konulu lisansüstü çalışmalar kapsamında nitel yaklaşıma dayalı, YÖK ulusal tez merkezi veri tabanında yapılan tarama neticesinde 2010-2020 yılları arasında yapılmış (son on yıldaki) 32 çalışma ile sınırlıdır. Literatür taramasında Sınıf Eğitimi bilim dalında çocuk edebiyatı konulu çalışmaların bazılarında karma yöntemin kullanıldığı görülmüştür. Ancak araştırmada nitel yaklaşımla yapılan çalışmaların ele alınması sebebiyle karma yöntemle yapılan araştırmalar kapsamın dışında tutulmuştur. Araştırmada incelenen lisansüstü çalışmalara kaynakçada yer verilmiştir.

\section{Yöntem}

\section{Araştırma Deseni}

Bu araştırma, Türkiye'de sınıf eğitimi bilim dalında çocuk edebiyatı konulu nitel yöntemle çalışılmış lisansüstü tezlerin incelenmesi amacıyla meta-sentez yaklaşımının kullanıldığı bir araştırmadır. Meta-sentez, bir konu üzerinde ortaya konmuş araştırmaların belirli temalar veya ana şablonlar çerçevesinde incelenmesi, sentezlenmesi ve yorumlanması olarak tanımlanmaktadır (Çalık ve Sözbilir, 2014, s.34; Dinçer, 2018, s.180). Ayrıca meta-sentez çalışmaları belirli bir alan veya konuda yapılan çalışmaların nitel bulgularının benzer ve farklı yönlerinin ortaya konulmasını ve ulaşılan bulgulardan yeni çıkarımlar yapılmasını amaçlar (Polat ve Ay, 2016, s.54-55). Bu doğrultuda araştırmacı, çalışmalar arasındaki benzerlik ve farklılıkları belirlemek amacıyla tema ve alt temaları oluşturarak çalışmaları nesnel bir yolla yorumlamaya çalışır (Ertekin ve Bozkurt, 2020, s.616). Sonuçta daha önceki çalışmaların nitel bulguları ve sonuçları karşılaştırılarak yeniden yorumlanır. Yapılan değerlendirmeler ile kesin bir sonuca erişme amaçlanmamaktadır; var olanı, çelişkili sonuçları ortaya çıkarmayı amaçlayan bir çalışma ortaya konur (Dinçer, 2018, s.180).

Verilerin Toplanması ve Araştırmaya Dâhil Edilme Kriterleri: Meta sentez çalışmalarında sürecin ve bulguların detaylı bir şekilde açıklanması oldukça önemlidir. Sürece ilişkin işlem adımları Şekil 1'e göre gerçekleştirilebilir (Polat ve Ay, 2016, s.55): 
- Araştırma sorularının belirlenmesi

- Çalışmanın konusuna uygun anahtar kelimelerin belirlenerek, alanyazın taramasinın yapılması

- Kaynakların taranması, değerlendirilmesi

- Araştırmanın dâhil edilme ve hariç tutulma ölçütlerinin

4. belirlenmesi, araștırmaya dâhil edilecek çalıșmaların seçilmesi

- Seçilen çalışmaların çözümlenmesi, tema ve kodların olușturulmasi

- Elde edilen bulgulardan çıkarımlar yapılması

- Sürecin ve bulguların ayrıntılı bir şekilde raporlaştırılması

Şekil 1. Meta sentez çalışması işlem basamakları

Araştırma süreci aşağıda belirtildiği şekliyle gerçekleştirilmiştir:

1. Aşama: Araştırmada Sınıf Eğitimi bilim dalında çocuk edebiyatı konulu lisansüstü çalışmaların mevcut durumunun nasıl şekillendiğini ortaya koymak amacıyla araştırma soruları oluşturulmuştur.

2. Aşama: Sınıf Eğitimi bilim dalında çocuk edebiyatı ile ilgili lisansüstü çalışmalara ulaşılabilecek anahtar kelimeler; "Temel Eğitim”, “İlköğretim”, "Sınıf Eğitimi”, "çocuk edebiyatı”, “çocuk kitapları" kavramları olmak üzere belirlenmiştir.

3. Aşama: Çalışmalar YÖK Ulusal Tez Merkezi veri tabanından seçilmiştir. Dâhil edilme ölçütleri: "lisansüstü çalışmaların 20102020 yılları arasını kapsaması, Türkiye' de yayımlanmış olması, Sınıf Eğitimi bilim dalında yapılmış olup nitel yöntemle ele alınmış olması" olarak kararlaştırılmıştır.

4. Aşama: YÖK Ulusal Tez Merkezi'nde erişime açık olmayan çalışmalar araştırma kapsamı dışında tutulmuştur. Çalışmalar 20102020 yılları arasıyla sınırlandırılmıştır.

Özellikle son on yılda yapılan çalışmaların seçilmesiyle, Sınıf Eğitimi bilim dalı çocuk edebiyatı alanında değişim ve gelişimin yansıtılması, bu 
alandaki yapılan çalışmaları takip etmek isteyen öğretmen ve araştırmacılara bilgi sağlanması amaçlanmıştır. Karma çalışmalar, araştırma kapsamına dâhil edilmemiştir. Çocuk edebiyatı ile ilgili tezlerin anabilim dalları incelenerek sınıf eğitimi olanlar tespit edilmiş, bir tezin anabilim dalı ile ilgili karar verilmesi için tez yazarına ulaşılmış ve çalışmaya dâhil edilmiştir. Tüm bu işlemlerden sonra araştırma, 1 doktora, 31 yüksek lisans tez çalışması ile yürütülmüştür.

1. Aşama: Araştırmaya dâhil edilen lisansüstü tezlerin değerlendirilmesinde temalar ve kodlar belirlenmiştir. Kodlamalar bağımsız olarak iki araştırmacı tarafından gerçekleştirilmiştir.

2. Aşama: Elde edilen bulgular sentezlenerek çıarımlarda bulunulmuştur.

3. Aşama: $\mathrm{Bu}$ araştırma kapsaminda tezler, temalara uygun bir şekilde tablo halinde sunulmuştur. Verilerin sunumunda bir görselin kullanılması okuyucuya ilk bakışta fikir sahibi olabilme imkânı tanımasıdır. Her bir tablo altında genel bir açıklama yapıldıktan sonra tez çalışmalarında dikkat çeken kısımlar önem derecesine göre açıklanmış ve öne çıkan eğilimler raporlanmıştır.

\section{Verilerin Analizi Süreci}

Araştırmaya dâhil edilen tezler detaylı bir şekilde okunmuş ve elde edilen veriler bilgisayar ortamına aktarılmıştır. Araştırma problemlerine göre incelenen tezlere yönelik tema ve kodlamalar yapılmıştır. Araştırmaya dâhil edilen çalışmaların özet halde sunulabilmesi adına Tablo 1 hazırlanmıştır. Oluşturulan tabloda araştırmanın yayın kodu, konusu, araştırma deseni, çalışma grubu, veri toplama aracı, veri analiz yöntemi, inanırlık ve tutarlılık çalışmaları, sonuçlar ve öneriler başlıkları yer almıştır.

Tablo 1. Verilerin Özetlenmesi İçin Oluşturulan Tablo

\begin{tabular}{|c|c|c|c|c|c|c|c|c|}
\hline $\begin{array}{l}\text { Yayın } \\
\text { kodu }\end{array}$ & Konu & $\begin{array}{l}\text { Araştırma } \\
\text { Deseni }\end{array}$ & $\begin{array}{l}\text { Çalışma } \\
\text { Grubu }\end{array}$ & $\begin{array}{l}\text { Veri } \\
\text { Toplama } \\
\text { Aracı }\end{array}$ & $\begin{array}{l}\text { Veri Ana- } \\
\text { liz Yön- } \\
\text { temi }\end{array}$ & $\begin{array}{l}\text { İnanırlık } \\
\text { ve Tutarlı- } \\
\text { lik }\end{array}$ & Sonuçlar & Öneriler \\
\hline
\end{tabular}

Ayrıca çalışmalar türlerine göre kodlanmıştır. Bu kodlamada tezler, yüksek lisans ve doktora şeklinde düzenlenmiş ve Tablo 2'de sunulmuştur. 
Tablo 2. Çalışmaların Kodlanma Örneği

\begin{tabular}{ll}
\hline Çalışma Türü & Çalışma Kodu \\
\hline Sınıf Eğitimi Bilim Dalı Yüksek Lisans Tezi & AY_1, AY_2, AY_3 $\ldots$ \\
Sınıf Eğitimi Bilim Dalı Doktora Tezi & AD_1... \\
\hline
\end{tabular}

Çalışmalar yaklaşık dört aylık bir süre içinde incelenmiş, ilgili notlar bilgisayar ortamına aktarılmış, veri kaybı olmaması için veriler değişik tarihlerde tekrar kontrol edilmiştir. Ayrıca çalışmalara ilişkin kod ve temaların oluşturulması sürecinde araştırmacılar birbirinden bağımsız şekilde kodlama yapmıştır. Ardından tema ve kodlamalar karşılaştırılarak kod ve temalara son hali verilmiştir.

\section{Araştırmanın Geçerlilik ve Güvenilirliği}

Kodlama sırasında herhangi bir hata olmaması için çalışmalar tez merkezinden indirildikten sonra tekrar kontrol edilmiştir. Araştırma soruları doğrultusunda kodlamalar iki araştırmacı tarafından ayrı ayrı gerçekleştirilmiştir. Kodlama güvenirliğini sağlamak için araştırmacı analizleri tekrar yapılmış, kodlamaların birbiri ile uyumu her başlık altında ayrı ayrı hesaplanmıştır. Farklı analiz sonuçları tartışılarak farklılıklar giderilmeye çalışılmıştır. Yıldırım ve Şimşek (2018)'e göre, bir araştırmada birden fazla araştırmacıya ait veri analizinde, kodlama güvenirliğinin sağlanması için bir çalışma yapılmalıdır. Çalışmanın sonucunda en az \%70 düzeyinde bir güvenirlik yüzdesine ulaşılmalıdır. Miles ve Huberman'a (2015) ait formülle yapılan hesaplamalarda güvenirlik katsayısı sırasıla; Konu Alanlarına yönelik \%87, Araştırma Desenlerine yönelik \%83, Çalışma Gruplarına Yönelik \% 87, Veri Toplama Araçlarına yönelik \%90, Veri Analiz Sürecine ilişkin \%90, İnanırlık ve Tutarlılık başlı̆̆ına ilişkin \% 75, Sonuçlara ilişkin \%100 ve Önerilere ilişkin \% 94 olarak hesaplanmıştır. Güvenirlik katsay1larına bakıldığında da araştırmanın kodlayıcı uyumu açısından güvenilir olduğu söylenebilir.

\section{Bulgular}

Çalışmanın bulguları her bir alt problem için ayrı ayrı sunulmuştur. 
Sınıf Eğitimi Bilim Dalında Çocuk Edebiyatı Konulu Lisansüstü Çalışmaların Konu Alanlarına İlişkin Bulgular: Tablo 3'te araştırmanın birinci alt probleminde ifade edilen sınıf eğitimi bilim dalında çocuk edebiyatı konulu lisansüstü çalışmaların konu alanlarına ilişkin bulgulara yer verilmiştir.

Tablo 3. Sınıf Ĕ̆itimi Bilim Dalında Çocuk Edebiyatı Konulu Lisansüstü Çalışmalarin Konu Alanlarna İlişkin Bulgular

\begin{tabular}{lll}
\hline Tema & Kod & Çalışmalar \\
\hline $\begin{array}{l}\text { Kitap/metin İnce- } \\
\text { leme }\end{array}$ & Eğitsel İletiler & AY_2, AY_7, AY_15, AY_17, AY_23, AY_4, \\
& AY_8 \\
& Değerler Eğitimi & AD_1, AY_3 AY_5, AY_6, AY_12, AY_13, \\
& AY_19, AY_20, AY_22, AY_25, AY_26, AY_27, \\
& AY_29, AY_31, AY_32 \\
& $\begin{array}{l}\text { Öğretmen/Veli Gö- } \\
\text { rüşleri }\end{array}$ & AY_24, AY_30, AY_18 \\
& $\begin{array}{l}\text { Yapı̈ Özellikleri } \\
\text { Toplumsal Farkın- } \\
\text { dalı }\end{array}$ & AY_9, AY_10, AY_13, AY_16, AY_14, AY_21 \\
& AY_11, AY_28 \\
&
\end{tabular}

Tablo 3 incelendiğinde Sınıf Eğitimi Bilim Dalında çocuk edebiyatı konulu lisansüstü çalışmaların konu çeşitliliği Kitap/metin İnceleme teması altında toplanmıştır. Kitap/metin İnceleme teması altında "Eğitsel İletiler", "Değerler Eğitimi”, “Öğretmen/Veli Görüşleri”, “Yapı Özellikleri”, “Toplumsal Farkındalık" kodlarının yer aldığı görülmektedir. Araştırmaların çoğunluğunun Kitap/metin İnceleme teması altında değerler eğitimi üzerine yapıldığ 1 tespit edilmiştir.

Sınıf Eğitimi Bilim Dalında Çocuk Edebiyatı Konulu Lisansüstü Çalışmaların Yöntemlerine İlişkin Bulgular: Bu başlık altında Sınıf Eğitimi Bilim Dalında Çocuk Edebiyatı Konulu Lisansüstü Çalışmaların yöntemlerine ilişkin bulgular araştırma deseni (Tablo 4), çalışma grubu seçimi (Tablo 5) ve veri toplama araçları (Tablo 6) başlıkları altında sunulmuştur.

Tablo 4'te çalışmaların araştırma desenleri incelendiğinde Desen Belirtilmiş ve Desen Belirtilmemiş olmak üzere iki tema oluşmuştur. Desen belirtilmiş teması altında "Betimsel Araştırma", "Durum Çalışması", "Doküman İncelemesi" ve "Tarama" kodları oluşmuştur. Araştırmaların “Doküman İncelemesi" kodu altında yoğunlaştığı görülmektedir. 
Tablo 4. Sınıf Eğitimi Bilim Dalında Çocuk Edebiyatı Konulu Lisansüstü Çalışmaların Araştırma Desenlerine İlişkin Bulgular

\begin{tabular}{lll}
\hline Tema & Kod & Çalışmalar \\
\hline & Betimsel Araştırma & AY_14, AY_20, AY_23 \\
& Durum Çalışması & AY_5, AY_8, AY_24, AY_30, AY_18 \\
& Doküman İncelemesi & AY_7, AY_9, AY_11, SY_12, AY_13, AY_15, \\
Desen Belirtilmiş & AY_17, AY_16, AY_19, AY_25, AY_26, AY_27 \\
& & AY_28, AY_29, AY_32, AY_2, AY_4, AY_10, \\
& AY_31 \\
& Tarama & AY_21, AY_22, AY_3 \\
& Eylem Araştırması & AD_1 \\
Desen Belirtilmemiş & & AY_6 \\
\hline
\end{tabular}

Tablo 5'te çalışmaların çalışma gruplarına ait bulgular Birey ve Doküman temaları altında toplanmıştır. Birey teması altında "İlkokul Öğrencileri”, “Okul Öncesi Öğrencileri”, “Sınıf Öğretmenleri”, “Okul Öncesi Öğretmenleri" ve "Veli" kodları yer alırken Doküman teması altında "Edebi Metin İncelemeleri”, “Ders Kitabı İncelemeleri” kodları yer almıştır. Yapılan çalışmaların çoğunlukla "Edebi metin inceleme" üzerine yoğunlaştığ 1 belirlenmiştir.

Tablo 5. Sınıf Eğitimi Bilim Dalında Çocuk Edebiyatı Konulu Lisansüstü Çalışmaların Çalışma Gruplarına İlişkin Bulgular

\begin{tabular}{lll}
\hline Tema & Kod & Çalışmalar \\
\hline \multirow{4}{*}{ Birey } & İlkokul öğrencileri & AD_1 \\
& Okul Öncesi öğrencileri & AY_6, AY_18 \\
& Sinıf Öğretmenleri & AY_24, AD_1 \\
& Okul Öncesi Öğretmen- & AY_30, AY_18, AY_6 \\
& leri & \\
& Veli & AY_18, AY_6 \\
& Edebi Metin İnceleme & AY_2, AY_3, AY_4, AY_5, \\
& & AY_6, AY_7, AY_8, AY_9, AY_10, AY_11, AY_12, \\
Doküman & AY_13, AY_14, AY_15, AY_17, AY_16, AY_19, \\
& & AY_20, AY_22, AY_23, AY_25, AY_26, AY_27, \\
& & AY_28, AY_29, AY_31, AY_32 \\
& & AY_21 \\
& Ders Kitabı İncelemeleri &
\end{tabular}

Tablo 6'da çalışmaların veri toplama araçlarına dair bulgular Doküman, Görüşmeler, Anket ve Ses/Video Kaydı temaları altında toplanmıştır. Bunlar- 
dan Doküman teması altında "Edebi Metinler", "Formlar ve Kontrol Listesi" kodları ön plana çıkarken; Görüşmeler teması altında "Yarı Yapılandırılmış" kodu; Anket teması altında "Demografik/Bilgi" kodu, Ses/Video Kaydı teması altında da "video kaydı" kodu ön plana çıkmıştır. Genel olarak çalışmaların büyük bir çoğunluğunun "Doküman" teması altında toplandığ1 görülmektedir.

Tablo 6. Sınıf Eğitimi Bilim Dalında Çocuk Edebiyatı Konulu Lisansüstü Çalışmaların Veri Toplama Araçlarına İlişkin Bulgular

\begin{tabular}{lll}
\hline Tema & Kod & Çalışmalar \\
\hline Doküman & Edebi Metinler & AY_2, AD_1, AY_3, AY_6, AY_7, AY_10, \\
& & AY_12, AY_14, AY_15, AY_17, AY_19, AY_20, \\
& AY_21, AY_22, AY_23, AY_25, AY_26, AY_27, \\
& AY_28, AY_29, AY_31, AY_32 \\
& Formlar & AD_1, AY_6, AY_9, AY_11, AY_13, AY_12, \\
& AY_14, AY_19, AY_28, AY_16, AY_8, AY_18 \\
& Kontrol Listesi & AY_4, AY_5, AY, 20 \\
Görüşmeler & Yarı Yapilandırılmış & AY_24, AY_30, AD_1 \\
Anket & Demografik/Bilgi & AY_24 \\
Ses/Video & Video Kaydi & AD_1 \\
Kayd1 & & \\
\hline
\end{tabular}

Çocuk edebiyatı üzerine yapılan çalışmalarda konunun farklı boyutlarının da ele alınmasını sağlayacak farklı veri toplama araçları (yarı yapılandırılmış görüşme, anket) son yıllarda kullanıldığı belirlenmiştir.

\section{Sınıf Ĕ̆itimi Bilim Dalında Çocuk Edebiyatı Konulu Lisansüstü Çalış-} maların Veri Analiz Sürecine İlişkin Bulgular: Araştırmanın üçüncü alt probleminde ifade edilen Sınıf Eğitimi Bilim Dalında Çocuk Edebiyatı Konulu Lisansüstü Çalışmaların Veri Analiz Sürecine İlişkin Bulgular veri analiz yöntemleri (Tablo 7) ile inanılırlık ve tutarlılık (Tablo 8) başlıkları altında sunulmuştur.

Tablo 7'de çalışmaların veri analizine ilişkin bulgular Analiz Yöntemleri teması altında "İçerik Analizi", "Betimsel Analiz", "Doküman Analizi ve "Belirtilmemiş" kodları ile ifade edilmiştir. Yapılan inceleme sonucunda analiz yöntemi belirtilmeyen tezlerde her ne kadar içerikten araştırmada kullanılan analiz yöntemi tespit edilse de veri analizi başlığ ${ }_{1}$ altında belir- 
tilmediği için "Belirtilmemiş" kategorisinde yer almıştır. Veri analiz yöntemlerini belirlemek çalışmanın kapsamında olmadığı için var olan durumu ortaya koymak amaçlanmıştır.

Tablo 7. Sınıf Ĕ̆itimi Bilim Dalında Çocuk Edebiyatı Konulu Lisansüstü Çalışmaların Veri Analizine İlişkin Bulgular

\begin{tabular}{lll}
\hline Tema & Kod & Çalışmalar \\
\hline & İçerik & AD_1, AY_2, AY_5, AY_6, AY_7, AY_8, AY_12, AY_13, AY_14, \\
& Analizi & AY_15, AY_17, AY_19, AY_20, AY_23, AY_30, AY_31 \\
Analiz & Betimsel & AY_5, AY_10, AY_12, AY_17, AY_21, AY_22, AY_24, AY_25, \\
Yöntem- & Analiz & AY_26, AY_27, AY_28, AY_29, AY_18 \\
leri & $\begin{array}{l}\text { Doküman } \\
\text { Analizi }\end{array}$ & AY_10, AY_11, AY_16 \\
& $\begin{array}{l}\text { Belirtilme- } \\
\text { miş }\end{array}$ & AY_3, AY_4, AY_9, AY_32 \\
& \\
\hline
\end{tabular}

Tablo 8'de çalışmaların inanılırlık ve tutarlılıklarına dair bulgular İnandırıcılık, Aktarılabilirlik ve Tutarlılık temaları altında toplanmıştır.

Tablo 8. Sını Eğitimi Bilim Dalında Çocuk Edebiyatı Konulu Lisansüstü Çalışmalarda İnanırlık ve Tutarlılık ile İlişkin Bulgular

\begin{tabular}{|c|c|c|}
\hline Tema & Kod & Çalışmalar \\
\hline & Çeşitleme & $\begin{array}{l}\text { AY_6, AD_1, AY_18, } \\
\text { AY_2, AY_7, AY_13, AY_6, AY_14, AY_30, AY_28, AY_8, }\end{array}$ \\
\hline İnandırıcılık & $\begin{array}{l}\text { Uzman incele- } \\
\text { mesi } \\
\text { Katılımci teyidi }\end{array}$ & $\begin{array}{l}\text { AD_1, AY_20, AY_11, AY_25, AY_5, AY_15, AY_31, } \\
\text { AY_16, AY_18, AY_19, AY_9, AY_24 } \\
\text { AY_6, AY_30, AD_1, }\end{array}$ \\
\hline \multirow{2}{*}{$\begin{array}{l}\text { Aktarabilirlik } \\
\text { (Transfer Edebi- } \\
\text { lirlik) }\end{array}$} & $\begin{array}{l}\text { Ayrıntılı betim- } \\
\text { leme (doğrudan } \\
\text { alıntı) }\end{array}$ & $\begin{array}{l}\text { AY_23, AY_3, AY_32, AY_2, AY_7, AY_13, AY_29, AY_6, } \\
\text { AY_22, AY_14, AY_17, AY_30, AY_28, AY_8, AY_21, } \\
\text { AY_12, AD_1, AY_11, AY_25, AY_10, AY_4, AY_5, AY_15, } \\
\text { AY_31, AY_19, AY_24, AY_26 }\end{array}$ \\
\hline & $\begin{array}{l}\text { Amaçlı örnek- } \\
\text { leme (örneklem) }\end{array}$ & $\begin{array}{l}\text { AY_23, AY_32, AY_2, AY_7, AY_13, AY_27, AY_29, AY_6, } \\
\text { AY_30, AY_22, AY_14, AY_17, AY_28, AY_8, AY_21, } \\
\text { AY_12, AD_1, AY_20, AY_11, AY_25, AY_10, AY_4, AY_5, } \\
\text { AY_15, AY_31, AY_16, AY_18, AY_19, AY_9, AY_24, } \\
\text { AY_26 }\end{array}$ \\
\hline Tutarlık & $\begin{array}{l}\text { Tutarlılık incele- } \\
\text { mesi } \\
\text { (detaylı süreç } \\
\text { açıklaması) }\end{array}$ & $\begin{array}{l}\text { AY_23, AY_2, AY_7, AY_13, AY_6, AY_22, AY_14, AY_17, } \\
\text { AY_30, AY_28, AY_8, AY_21, AY_12, AD_1, AY_20, } \\
\text { AY_11, AY_25, AY_10, AY_4, AY_5, AY_15, AY_31, AY_16, } \\
\text { AY_18, AY_19, AY_9, AY_24 }\end{array}$ \\
\hline
\end{tabular}

Bunlardan İnandırıcılık teması altında "Çeşitleme, Uzman İncelemesi, Katılımcı Teyidi" kodları ön plana çıarken; Aktarılabilirlik teması altında 
"Ayrıntılı Betimleme, Amaçlı Örnekleme" ve Tutarlılık teması altında ise "Tutarlılık incelemesi" kodu ön plana çıkmıştır. İncelenen tezlerde inanılırlık ve tutarlılık boyutunu sağlamak için Aktarılabilirlik ve Tutarlılık kısmına yoğun olarak yer verilirken, İnandırıcılık kısmına daha az yer verilmiştir.

İlkokulda Sınıf Eğitimi Bilim Dalında Çocuk Edebiyatı Konulu Lisansüstü Çalışmaların Sonuçlarına İlişkin Bulgular: Tablo 9'da araştırmanın dördüncü alt probleminde ifade edilen ilkokulda sınıf eğitimi bilim dalında çocuk edebiyatı konulu lisansüstü çalışmaların sonuçlarına ilişkin bulgulara yer verilmiştir.

Tablo 9. Sınıf Eğitimi Bilim Dalında Çocuk Edebiyatı Konulu Lisansïstü Çalışmalarin Sonuçlarına İlişkin Bulgular

\begin{tabular}{|c|c|c|}
\hline Tema & Kod & Çalışmalar \\
\hline \multirow{4}{*}{$\begin{array}{l}\text { Hikaye/Kitap } \\
\text { İncelemesi/ } \\
\text { Değerlendirme }\end{array}$} & Değer vurgusu & $\begin{array}{l}\text { AD_1, AY_3, AY_5, AY_6, AY_10, } \\
\text { AY_12, AY_13, AY_19, AY_20, } \\
\text { AY_22, AY_25, AY_26, AY_27, } \\
\text { AY_29, AY_31, AY_32 }\end{array}$ \\
\hline & $\begin{array}{l}\text { Eğitsel iletilerin/kavramların sunul- } \\
\text { ması }\end{array}$ & 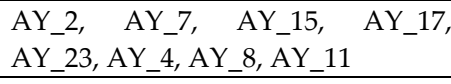 \\
\hline & $\begin{array}{l}\text { İncelenen çalışmaların dış yapı özel- } \\
\text { likleri açısından uygunluğunun be- } \\
\text { lirlenmesi }\end{array}$ & $\begin{array}{l}\text { AY_7, AY_11, AY_9, AY_10, AY_13, } \\
\text { AY_16, AY_21, AY_28, AY_18 }\end{array}$ \\
\hline & $\begin{array}{l}\text { İncelenen çalışmaların iç yapı özel- } \\
\text { likleri açısından uygunluğunun be- } \\
\text { lirlenmesi }\end{array}$ & $\begin{array}{l}\text { AY_7, AY_11, AY_9, AY_10, AY_12, } \\
\text { AY_13, AY_14, AY_16, AY_21, } \\
\text { AY_22, AY_28, AY_32, AY_18 }\end{array}$ \\
\hline \multirow{3}{*}{$\begin{array}{l}\text { Dersin İşle- } \\
\text { nişi/Öğretim } \\
\text { Çalışmaları }\end{array}$} & $\begin{array}{l}\text { Farklı öğretim tekniklerinin kullanı- } \\
\text { mının olumlu etkisi }\end{array}$ & AD_1 \\
\hline & $\begin{array}{l}\text { Öğretmenlerin çocuk kitaplarının } \\
\text { disiplinler arası kullanımına ilişkin } \\
\text { görüşleri }\end{array}$ & AY_24 \\
\hline & $\begin{array}{l}\text { Kitap seçme kriterlerinin belirlen- } \\
\text { mesi }\end{array}$ & AY_30 \\
\hline
\end{tabular}

Tablo 9'da çalışmaların sonuçlarına dair bulgular Hikâye/Kitap İncelemesi/Değerlendirilmesi, Dersin İşleniş̧i/Öğretim Çalışmaları temaları altında toplanmıştır. Bu temalardan Hikâye/Kitap İncelemesi/Değerlendirilmesi altında "Değer vurgusu", "Eğitsel iletilerin/kavramların sunulması" ve "İn- 
celenen çalışmaların dış yapı özellikleri açısından uygunluğunun belirlenmesi" ve "İncelenen çalışmaların iç yapı özellikleri açısından uygunluğunun belirlenmesi" kodları ön plana çıkmıştır.

Dersin İşlenişi/Öğretim Çalışmaları teması altında "Farklı yöntemlerin kullanımının olumlu etkisi" ve "Öğretmenlerin çocuk kitaplarının disiplinler arası kullanımına ilişkin görüşleri" ve "Kitap seçme kriterlerinin belirlenmesi" kodları ortaya çıkmıştır.

\section{İlkokulda Sınıf Eğitimi Bilim Dalında Çocuk Edebiyatı Konulu Lisan- süstü Çalışmaların Sonuçlarına Yönelik Önerilere İlişkin Bulgular:}

Tablo 10 ' da beşinci alt problemde ifade edilen ilkokulda Sınıf Eğitimi bilim dalında çocuk edebiyatı konulu lisansüstü çalışmaların sonuçlarına yönelik önerilere dair bulgular yer almaktadır.

Tablo 10. Sınıf Eğitimi Bilim Dalında Çocuk Edebiyatı Konulu Lisansüstü Çalışmaların Sonuçlarnna Yönelik Önerilerine İlişkin Bulgular

\begin{tabular}{|c|c|c|}
\hline Tema & Kod & Çalışmalar \\
\hline \multirow{10}{*}{$\begin{array}{l}\text { Çocuk Edebiyatı } \\
\text { Ürünlerinin İçeri- } \\
\text { ğine Yönelik Öneri- } \\
\text { ler }\end{array}$} & $\begin{array}{l}\text { Konuyla ve işlenen değerlerle ilgili } \\
\text { daha etkili, estetik ve çocuklara hitap } \\
\text { eden resimler konulmalı }\end{array}$ & AY_9, AY_10, AY_16 \\
\hline & $\begin{array}{l}\text { Çeviri ve yerli eserlerde yapılan sa- } \\
\text { deleştirmelerde bir ölçüt olmalı }\end{array}$ & AY_13 \\
\hline & $\begin{array}{l}\text { Dil ve anlatım yönünden uygun ol- } \\
\text { malı }\end{array}$ & AY_16, AY_2 \\
\hline & Dış yapı özelliklerine uygun olmalı & AY_16, AY_18, AY_10, AY_13 \\
\hline & $\begin{array}{l}\text { Çocuğun öğrenilmiş davranış özel- } \\
\text { liklerine uygun; çocuğun kişisel, top- } \\
\text { lumsal ve sosyal yönden gelişimini } \\
\text { destekleyici eğitsel iletilere/değerlere } \\
\text { ağırlık vermeli }\end{array}$ & $\begin{array}{l}\text { AY_2, AY_5, AY_3, AY_6, AY_7, AY_9, } \\
\text { AY_13, AY_16, AY_17, AY_20, AY_23, } \\
\text { AY_28, AY_32, AY_18 }\end{array}$ \\
\hline & Öğretmenlerin katkısı araştırılmalı & AD_1 \\
\hline & $\begin{array}{l}\text { Disiplinlerarası bir yaklaşımla çalışıl- } \\
\text { malı }\end{array}$ & AY_31 \\
\hline & $\begin{array}{l}\text { Çocuk edebiyatı alanındaki nitelikli } \\
\text { eserlerin, okuma kültürüne etkisini, } \\
\text { dil eğitimine ve Türkçe öğretimine } \\
\text { katkısını araştıran tezler/çalışmalar } \\
\text { yapılmalı }\end{array}$ & AY_19 \\
\hline & $\begin{array}{l}\text { Farklı yazar ve metin türleri/kitaplar, } \\
\text { incelenmeli }\end{array}$ & AY_6, AY_8, AY_12, AY_31 \\
\hline & $\begin{array}{l}\text { Araştırmacilar bireyi, bireyin sosyal } \\
\text { çevresini ve bireyin ailesinin sosyal- }\end{array}$ & AD_1, AY_28 \\
\hline
\end{tabular}


Sınıf Eğitimi Bilim Dalı'nda Çocuk Edebiyatı Konulu Lisansüstü Çalışmalara Genel Bakış: Bir Meta-Sentez Çalışması

\begin{tabular}{|c|c|c|}
\hline \multirow{7}{*}{$\begin{array}{l}\text { Gelecekteki Araştır- } \\
\text { malara Yönelik } \\
\text { Öneriler }\end{array}$} & \multicolumn{2}{|l|}{$\begin{array}{l}\text { kültürel yapısını ile sosyoekonomik } \\
\text { düzeyini tanımalı }\end{array}$} \\
\hline & Kültürlerarası çalışmalar yapılmalı & AY_5, AY_28 \\
\hline & $\begin{array}{l}\text { İç Yapı ve dış yapı özellikleri bakı- } \\
\text { mından incelenmeli }\end{array}$ & $\begin{array}{l}\text { AY_6, AY_10, AY_11, AY_23, AY_28, } \\
\text { AY_3, AY_9 }\end{array}$ \\
\hline & $\begin{array}{l}\text { Çocukların kitap seçme motivasyon- } \\
\text { ları incelenmeli }\end{array}$ & AY_19 \\
\hline & $\begin{array}{l}\text { Farklı çalışma gruplarıyla/farklı ko- } \\
\text { nularda çalışmalar yapılmalı }\end{array}$ & AY_24, AY_30 \\
\hline & $\begin{array}{l}\text { Nitel yöntemlerin kullanıldığı farklı } \\
\text { çalışmalar yapılmalı }\end{array}$ & AD_1, AY_14, AY_20, AY_30 \\
\hline & $\begin{array}{l}\text { Nicel yöntemlerin kullanıldığı ça- } \\
\text { lışma yapılmalı }\end{array}$ & AY_6, AY_9, AY_28 \\
\hline \multirow{3}{*}{$\begin{array}{l}\text { Erişim /Ulaşılabilir- } \\
\text { liğe İlişkin Öneriler }\end{array}$} & $\begin{array}{l}\text { Kütüphaneler/Kitaplıklar oluşturul- } \\
\text { malı }\end{array}$ & AY_6, AY_27, AY_30 \\
\hline & $\begin{array}{l}\text { Klasiklerin basımını yapan yayınevi } \\
\text { sayısının kısıtlanması }\end{array}$ & AY_13 \\
\hline & $\begin{array}{l}\text { İnternet üzerinden değer kategorile- } \\
\text { rine uygun kitap listelerinin olduğu } \\
\text { bir portal oluşturulmalı }\end{array}$ & AY_20 \\
\hline $\begin{array}{l}\text { Program Geliştir- } \\
\text { meye Yönelik Öne- } \\
\text { riler }\end{array}$ & $\begin{array}{l}\text { Sosyal farkındalığı artırmaya yönelik } \\
\text { (Zorbalık, engelli olma, göçmenlik } \\
\text { vs.) programların/çalışmaların geliş- } \\
\text { tirilmesi }\end{array}$ & AY_4, AY_11, AY_8 \\
\hline \multirow{3}{*}{$\begin{array}{l}\text { Sınıf İçi Uygulama } \\
\text { Sürecine İlişkin } \\
\text { Öneriler (Yakla- } \\
\text { şım/Yöntem ve Tek- } \\
\text { nik vs.) }\end{array}$} & $\begin{array}{l}\text { Uygun yöntem ve tekniklerle değer- } \\
\text { ler/kavramlar somutlaştırılarak öğre- } \\
\text { tilmeli }\end{array}$ & AD_1, AY_4, AY_17 \\
\hline & $\begin{array}{l}\text { Değerler/ kavramlar çeşitli öğretim } \\
\text { etkinlikleri ile sunulmalı }\end{array}$ & AD_1, AY_6, AY_14, AY_26, AY_30 \\
\hline & $\begin{array}{l}\text { Disiplinlerarası çeşitli etkinlikler ya- } \\
\text { pılmalı }\end{array}$ & AY_17, AY_19, AY_24 \\
\hline \multirow{6}{*}{$\begin{array}{l}\text { Geleceğe Yönelik } \\
\text { Proje Önerileri }\end{array}$} & $\begin{array}{l}\text { Araştırmalarda sosyal ve kültürel fa- } \\
\text { aliyetlere, sosyal sorumluluk projele- } \\
\text { rine daha fazla yer verilmeli }\end{array}$ & AD_1, AY_11, AY_31 \\
\hline & $\begin{array}{l}\text { Çocuk edebiyatı eserlerinin sonunda } \\
\text { sunulan değerlerle ilgili sorular, ya- } \\
\text { yınevleri tarafından değerleri pekiş- } \\
\text { tirme adına çocuk edebiyatçllarının } \\
\text { eserlerine de konulmalı }\end{array}$ & AY_3 \\
\hline & $\begin{array}{l}\text { Sosyal medya, çizgi film, youtube, e- } \\
\text { kitap, video paylaşım platformları } \\
\text { aracılığıyla değer ve kavram aktarımı } \\
\text { gerçekleştirilmeli }\end{array}$ & AY_4, AY_12, AY_15, AY_17, AY_31 \\
\hline & $\begin{array}{l}\text { Ders kitapları hazırlanırken çocuk } \\
\text { edebiyatı ürünlerinden yararlanıl- } \\
\text { malı }\end{array}$ & $\begin{array}{l}\text { AY_8, AY_12, AY_14, AY_17, AY_21, } \\
\text { AY_22, AY_23, AY_25, AY_29, AY_31, } \\
\text { AY_32 }\end{array}$ \\
\hline & $\begin{array}{l}\text { Klasik eserler niteliğinde yeni çocuk } \\
\text { kitapları yazılmalı }\end{array}$ & AY_13 \\
\hline & $\begin{array}{l}\text { Çocuk edebiyatı yazar ve eserlerine } \\
\text { yönelik bilimsel etkinlik (sempoz- } \\
\text { yum, konferans vs.) düzenlenmeli }\end{array}$ & AY_22 \\
\hline
\end{tabular}




\begin{tabular}{lll}
\hline & Öğretmen, ebeveyn ve eğitimcilerin & AY_2, AD_1, AY_5, AY_9, AY_11, \\
Farkındalık Oluş- & çocuk kitapları ile ilgili farkındalık & AY_13, AY_16, AY_19, AY_20, AY_21, \\
turmaya Yönelik & kazanması & AY_22, AY_23, AY_31, AY_32, AY_18, \\
Öneriler & AY_27 \\
\cline { 2 - 3 } & $\begin{array}{l}\text { Lisans/Lisansüstü, hizmet içi eğitim } \\
\text { programları oluşturulmalı }\end{array}$ & AY_4, AY_24, AY 27, AY_30 \\
& \\
\hline
\end{tabular}

Tablo 10'da çalışmaların sonuçlarına yönelik önerilerin bulguları Çocuk Edebiyatı Ürünlerinin İçeriğgine Yönelik Öneriler, Gelecekteki Araştırmalara Yönelik Öneriler, Erişim /Ulaşılabilirliğe İlişkin Öneriler, Program Geliştirmeye Yönelik Öneriler, Sinıf İçi Uygulama Sürecine İlişkin Öneriler, Geleceğe Yönelik Proje Önerileri, Farkındalık Oluşturmaya Yönelik Öneriler temaları altında toplanmıştır. Bu temalardan Çocuk Edebiyatı Ürünlerinin İçeriğine Yönelik Öneriler altında çocuk edebiyatı ürünlerinin dış yapı özellikleri, değer/ileti sunumu, dil ve anlatım hususunda öneriler yapılmıştır. Gelecekteki Araştırmalara Yönelik Öneriler teması altında iç yapı ve dış yapı özellikleri, araştırma yöntemi, çalışma gruplarına yönelik önerilerde bulunulmuştur. Erişim /Ulaşılabilirliğge İlişkin Öneriler teması altında kütüphane/ kitaplık oluşturulması, internet üzerinden bir portal oluşturulması hususunda öneriler sunulmuştur. Program Geliştirmeye Yönelik Öneriler teması altında sosyal farkındalığı artırmaya yönelik programların geliştirilmesine ilişkin önerilerde bulunulmaktadır. Sınıf İçi Uygulama Sürecine İlişkin Öneriler teması altında çeşitli yöntem ve tekniklerin uygulanması, disiplinlerarası etkinlikler yapılmasına ilişkin önerilerde bulunulmaktadır. Geleceğe Yönelik Proje Önerileri sosyal sorumluluk projelerinin hazırlanması, ders kitaplarının hazırlanışında çocuk edebiyatı ürünlerinden faydalanılması, ürünlerin farklı platformlar üzerinden paylaşılması hususunda öneriler sunulmuştur. Farkındalık Oluşturmaya Yönelik Öneriler teması altında ise öğretmen, ebeveyn ve eğitimcilerin çocuk kitaplarıyla ilgili farkındalık kazanması, lisans/lisansüstü ve hizmet içi eğitim programlarının oluşturulması ve toplumsal farkındalığı sağlamak amacıyla çalışmalar yapılması hususunda öneriler sunulmuştur.

\section{Sonuçlar, Tartışma ve Öneriler}

Araştırmada Sınıf Eğitimi bilim dalında çocuk edebiyatı konulu lisansüstü çalışmalar analiz edilmiş ve sırasıyla şu sonuçlara ulaşılmıştır. 
Araştırmanın birinci alt problemindeki Sınıf Eğitimi bilim dalında çocuk edebiyatı konulu lisansüstü çalışmaların konu alanlarına ilişkin sonuçlar incelendiğinde çalışma konularının yoğunlukla çocuk edebiyatı eserlerini inceleme üzerine olduğu görülmüş̧ür. Bu bulgu Balcı'nın (2012), 1981 ve 2010 yılları arasında Türkiye'de çocuk edebiyatı üzerine yapılan yüksek lisans tezlerini analiz ettiği çalışmasında, tezlerin konusuna göre dağılımıyla ilgili bulgusu ile örtüşmektedir. Ayrıca Bayazıt (2011), çocuk edebiyatı alanında yapılan lisansüstü tezlerin incelenmesi (2010 yıl sonuna kadar) başlıklı çalışmasında konuların çocuk edebiyatı yazarları ve yapıtları/görüşleri konusu üzerine yoğunlaştığını ifade etmiştir. Bu durum da 2010 yılı öncesi ve 2010 yılı sonrası (Sevim, 2020; Şahin ve Toprak, 2021) yapılan tez konularının aynı doğrultuda seçildiğini göstermektedir. Ayrıca çocuk edebiyatına dair eserler incelenirken değerler eğitimi yönüyle ele alınmıştır. Bu sonuç; Sevim (2020), Şahin ve Toprak'ın (2021) çalışmalarının sonuçlarıyla örtüşmektedir. Çocuk edebiyatı konusu alanında yapılan çalışmaların sadece edebi açıdan eser incelemesi ile sinırlandırılmayıp edebi eserlerin farklı disiplinler (psikoloji, tasarım, felsefe, sosyoloji vd.) ile kritik edilmesi yazılacak eserlerin niteliğini artırabileceği düşünülmektedir.

Sınıf Eğitimi bilim dalında çocuk edebiyatı konulu lisansüstü çalışmaların yöntemlerinin ele alındığı ikinci alt problemde; çalışmalarda çoğunlukla doküman incelemesi yönteminin kullanıldığı görülmektedir. Bu sonuç Balta (2019), Bayazıt (2011), Şahin ve Toprak (2021) ve Atalay Yakar'ın (2019) sonuçlarıyla örtüşmektedir. Fakat çalışmalarda nitel ve nicel araştırma yöntemlerinin birlikte kullanımı verilerin derinlemesine analizinde katkı sağlaması açısından yararlı olabilir.

Sınıf Eğitimi bilim dalında çocuk edebiyatı konulu lisansüstü çalışmaların çalışma gruplarına ilişkin sonuçlarda daha çok edebi metinlerle çalışıldığı tespit edilmiştir. Çalışma grupları bakımından öğretmen/öğrenci/veli gruplarıyla da yapılan az sayıda çalışma olduğu görülmüştür. Sınıf Eğitimi bilim dalında çocuk edebiyatı konulu lisansüstü çalışmaların veri toplama araçlarına ilişkin sonuçlarda, çoğunlukla edebi metinler ve formlar veri toplama aracı olarak kullanılmıştır. Görüşme, anket, ses/video kaydı gibi veri toplama araçlarının kullanıldığı çalışma sayısı oldukça sinirlidir. 
Araştırmanın üçüncü alt probleminde belirtilen Sınıf Eğitimi bilim dalında çocuk edebiyatı konulu lisansüstü çalışmaların veri analiz sürecine ilişkin sonuçlarda içerik analizi ve betimsel analiz yoğun olarak kullanılan analiz yöntemlerinden olmuştur. Balta (2019), Sevim (2020) de yaptıkları çalışmalarda da betimsel analizin araştırmacıların başvurduğu ilk üç teknik içerisinde yer aldığı sonucuna ulaşmışlardır. Lisansüstü çalışmalarda geçerlilik ve güvenirliğe ilişkin sonuçlarda inandırıcılık, aktarılabilirlik ve tutarlılık temaları belirlenmiştir. Çalışmalarda inandırıcılığı sağlamak bakımından daha çok uzman görüşü alınırken, az sayıda çalışmada da katılımcı teyidi ve çeşitlemeye başvurulmuştur. Çalışmalarda aktarılabilirlik noktasında hem doğrudan alıntı hem de çalışma gruplarıyla ilgili detaylı bir şekilde açıklamalara yer verilmiştir. Ayrıca çalışmaların büyük bir kısmında araştırma süreci detaylı açıklanarak tutarlılık sağlanmaya çalışımiştır.

Sınıf eğitimi bilim dalında çocuk edebiyatı konulu lisansüstü çalışmaların sonuçlarını içeren araştırmanın dördüncü alt problemine yönelik sonuçlarda; eser incelemesine bağlı olarak değer vurgusu ön plana çıkmıştır. Ayrıca sırasıyla çalışmalarda incelenen eserlerin iç yapı özelliklerinin uygunluğu, dış yapı özellikleri açısından uygunluğu ve eğitsel iletilere yönelik sonuçlara ulaşılmıştır. Aynı zamanda dersin işlenişi/öğretim çalışmalarına ilişkin sonuçlara ulaşan az sayıda çalışma bulunmaktadır. Bu doğrultuda incelenen çalışmalarda farklı öğretim tekniklerinin kullanımının olumlu etkisi, öğretmenlerin çocuk kitaplarının disiplinler arası kullanımına ilişkin görüşleri ve kitap seçme kriterlerinin belirlenmesine yönelik sonuçlara ulaşılmıştır.

Araştırmanın beşinci ve son alt probleminde belirtilen Sınıf Eğitimi bilim dalında çocuk edebiyatı konulu lisansüstü çalışmaların sonuçlarına yönelik önerilere ilişkin sonuçlarda, çocuk edebiyatı ürünlerinin içeriğine yönelik öneriler; çocuğun öğrenilmiş davranış özellikleriyle uyumlu; çocuğun kişisel, toplumsal ve sosyal özelliklerinin gelişimini destekleyen eğitsel iletilere/değerlere ağırlık verilmesi hususundaki önerilere birçok çalışmada yer verilmiştir. (Akçay (2015), Biros (2019), Bağcı (2013), Cengiz (2016), Cesur, 2015)). Çalışmalarda gelecekteki araştırmalara yönelik önerilerde ise çocuk edebiyatı eserlerinin iç yapı ve dış yapı özellikleri bakımından incelenmesi gerektiği vurgulanmıştır. Erişim ve ulaşılabilirliğe 
ilişkin önerilerde ise çocuklara yönelik kütüphane ve kitaplıklar oluşturulmalı önerisi ağırlık kazanmıştır. Sınıf içi uygulama sürecine ilişkin önerilerde ise çocuk edebiyatı eserlerinin içeriğinin farklı yaklaşım, yöntem ve tekniklerle sunulması gerektiği ön plana çıkarılmıştır. Geleceğe yönelik projeler için sunulan önerilerde ise ders kitapları hazırlanırken çocuk edebiyatı ürünlerinden yararlanılması yönünde tavsiyelere başvurulmuştur.

Gelecekteki Araştırmalara Yönelik Öneriler, Erişim /Ulaşılabilirliğe İlişkin Öneriler, Program Geliştirmeye Yönelik Öneriler, Sınıf İçi Uygulama Sürecine İlişkin Öneriler, Geleceğe Yönelik Proje Önerileri, Farkındalık Oluşturmaya Yönelik Öneriler temaları ön plana çıkmıştır. Bu temalardan Çocuk Edebiyatı Ürünlerinin İçeriğine Yönelik Öneriler altında çocuk edebiyatı ürünlerinin dış yapı özellikleri, değer/ileti sunumu, dil ve anlatım hususunda öneriler yapılmıştır. Gelecekteki Araştırmalara Yönelik Öneriler teması altında iç yapı ve dış yapı özellikleri, araştırma yöntemi, çalışma gruplarına yönelik önerilerde bulunulmuştur. Erişim /Ulaşılabilirliğe İlişkin Öneriler teması altında kütüphane/kitaplık oluşturulması, internet üzerinden bir portal oluşturulması hususunda öneriler görülmektedir. Program Geliştirmeye Yönelik Öneriler teması altında sosyal farkındalığı artırmaya yönelik programların geliştirilmesine ilişkin önerilerde bulunulmaktadır. Sınıf İçi Uygulama Sürecine İlişkin Öneriler teması altında çeşitli yöntem ve tekniklerin uygulanması, disiplinler arası etkinlikler yapılmasına ilişkin öneriler de görülmüştür. Geleceğe Yönelik Proje Önerileri sosyal sorumluluk projelerinin hazırlanması, ders kitaplarının hazırlanışında çocuk edebiyatı ürünlerinden faydalanılması, ürünlerin farklı platformlar üzerinden paylaşılması hususunda öneriler sunulmuştur. Farkındalık Oluşturmaya Yönelik Öneriler teması altında ise öğretmen, ebeveyn ve eğitimcilerin çocuk kitaplarıyla ilgili farkındalık kazanması, lisans/lisansüstü ve hizmet içi eğitim programlarının oluşturulması ve toplumsal farkındalığı sağlamak amacıyla çalışmalar yapılması hususunda öneriler ileri sürülmüştür. Son olarak öğretmen, ebeveyn ve eğitimcilerin çocuk kitapları ile ilgili farkındalık kazanmasına yönelik öneriler de yer almıştır.

\section{Öneriler}

Araştırmanın sonuçları doğrultusunda şu önerilerde bulunulabilir: 
Araştırmanın Sınıf Ĕ̆itimi bilim dalında yapılan çocuk edebiyatı konulu lisansüstü çalışmaların genellikle eser incelemesinde değerler eğitimi üzerine yapıldığı, toplumsal olayların ele alınması, öğretmen/veli görüşlerine yer verilmesi hususunda çalışmaların yetersizliğinden dolayı çocuk edebiyatı eserlerinin incelenmesinin faklı boyutlarıyla çalışılması,

Çalışmaların yoğun olarak doküman incelemesiyle ele alındığ 1 için bu alanda uygulamalı çalışmaların eksikliği görülmüştür. Bu nedenle çalışmalarda farklı araştırma desenlerinin kullanılması, araştırmanın doküman dışında farklı çalışma gruplarıyla (öğrenci, veli, öğretmen) tasarlanması, çalışmalarda veri toplama aracı olarak edebi metinlere ek olarak anket, görüşme formları, kontrol listeleri, ses/video kaydı gibi farklı veri toplama araçlarının kullanılması ayrıca çalışmaların yöntem kısmının daha detaylı ve açıkça ifade edilmesi,

Çalışmalarda geçerlilik ve güvenirliğin sağlanması hususunda yapılan çalışmaların tüm boyutlarıyla ele alınması ve ifade edilmesi, farklı yöntemler kullanılarak veri çeşitlemesi, katılımcı teyidi gibi boyutlara da yer verilmesi,

Çocuk edebiyatı eserlerinin öğrencilere aktarımında çeşitli yöntem ve tekniklerin kullanılması, eserlerin disiplinler arası yaklaşımla ele alınması, eserlerin değerlendirilmesi noktasında öğretmen, veli ve öğrenci görüşlerine de başvurulması,

Çocuk edebiyatı üzerine yapılacak olan araştırma veya projelerde nicel ve karma yöntemlere yer verilmesi, okuma kültürü ve okuma motivasyonu sağlanması hususunda çalışmalar yapılması, öğretim programlarında çocuk edebiyatı eserlerine farklı boyutlarıla yer verilmesi, eserlere ulaşılabilirlik ve erişilebilirliğini artırmaya yönelik faaliyetler gerçekleştirilmesi önerilebilir. 


\title{
EXTENDED ABSTRACT
}

\section{Overview of Graduate Studies on Children's Literature in the Science of Classroom Education: A Meta-Synthesis Study}

\author{
Hülya Kodan - Kürşad Kara \\ Bayburt University
}

One of the addresses that educators will turn to for the acquisition and development of students' language development and reading habits is children's literature. Children's literature is the name given to all of the linguistic and visual products that are prepared in accordance with the level of understanding and language development of children through fictional worlds, enrich their worlds of emotion, thought and imagination, and support their spiritual development during the life period between early childhood and adolescence.

In order for children's literature to fulfill the basic functions in the development of the child, it is important that the books contain the principle of appropriateness to the child, childlike sensitivity and child reality. Determining the literary and pedagogical needs of qualified books written in the field of children's literature, revealing both functional and aesthetic texts is possible as a result of in-depth academic studies. There have been many postgraduate studies on children's literature in the field of classroom education in Turkey. However, the limited number of studies examining; article has been found. In particular, the determination of data on children's literature, which has a great contribution to the development of reading skills of students at the basic education level, has not been seen in previous studies.

In this context, it is foreseen that the research will both be a source for qualified Turkish teaching and guide for researches in the field of Primary Education for the primary school period where the acquisition and development of reading habits is at the forefront. For this reason, it is aimed to reveal the trends related to graduate studies on children's literature in the field of Primary Education. 
The research is limited to 32 studies conducted between 2010-2020 (in the last ten years), based on a qualitative approach within the scope of postgraduate studies on children's literature in the field of Primary Education in Turkey, as a result of a search on the YÖK national thesis center database. And it is a research in which meta-synthesis approach is used in order to examine the postgraduate theses which were studied with qualitative method on children's literature in the field of primary education in Turkey. During the study, the theses included in the research were read in detail and the data obtained were transferred to the computer environment. Themes and codes were made for the theses examined according to the research problems.

When the results of the postgraduate studies on children's literature in the field of Primary Education were examined, it was seen that the study subjects were mostly on examining the works of children's literature. It is seen that the document analysis method is mostly used in studies. However, the combined use of qualitative and quantitative research methods in studies may be beneficial in terms of contributing to the in-depth analysis of the data. And In the results of the study groups of graduate studies on children's literature in Primary Education, it has been determined that mostly literary texts are studied.

In addition to these results, mostly literary texts and forms were used as data collection tools in the results of the data collection tools of the graduate studies on children's literature in the field of Primary Education. The number of studies using data collection tools such as interviews, questionnaires, audio/video recordings is quite limited. Content analysis and descriptive analysis have been the most frequently used analysis methods in the results of the data analysis process of graduate studies on children's literature in the field of Primary Education. The themes of credibility, transferability and consistency were determined in the results of validity and reliability in graduate studies.

Finally, in the suggestions for the results of graduate studies on children's literature in Primary Education, suggestions for the content of children's literature products; compatible with the child's learned behavioral characteristics; It has been seen in many studies that suggestions on giving weight to educational messages/values that support the development of the child's personal, social and social characteristics are included. In the 
studies, it was emphasized that the works of children's literature should be examined in terms of internal structure and external structure characteristics. In the suggestions regarding access and accessibility, the suggestion that libraries and libraries should be created for children gained weight. In the suggestions presented for future projects, recommendations were made to benefit from children's literature products while preparing textbooks. there are also suggestions for teachers, parents and educators to raise awareness about children's books. And preparatory suggestions for the projects of the Future Oriented Projects social responsibilities, the use of the books in the preparation of the course lessons, can be designed appropriately through different platforms.

\section{Kaynakça / References}

Akçay, S. (2015). Samed Behrengi'nin hikâyelerindeki eğitsel iletiler üzerine bir araştırma. (Yayımlanmamış Yüksek Lisans Tezi). İstanbul Aydın Üniversitesi, İstanbul.

Akdemir, S. (2019). Illkokul dördüncü sinıfta felsefe temelli çocuk kitapları yoluyla değerler eğitimine ilişkin bir eylem araştırması. (Doktora Tezi). Necmettin Erbakan Üniversitesi, Konya.

Atalay Yakar, F. (2019). Türkiye'de çocuk edebiyatı alanında yapılan lisansüstü çalışmaların içerik ve yöntem açısından incelenmesi. (Yayımlanmamış Yüksek Lisans Tezi). Burdur Mehmet Akif Ersoy Üniversitesi, Burdur.

Aytaş, G. (2003). Okuma gelişiminde çocuk edebiyatının rolü. Türklük Bilimi Araştırmaları, 13, 155-160.

Bağcı, E. (2013). Çocuk edebiyatı ürünleriyle çocuklar için yazılmış eserlerin değerler eğitimi bağlamında karşılaştıılması. (Yayımlanmamış Yüksek Lisans Tezi). Celal Bayar Üniversitesi, Manisa.

Balcı, A. (2012). Türkiye' de çocuk edebiyatı üzerine hazırlanan lisansüstü tezler hakkında bir meta-analiz çalışması. Mustafa Kemal Üniversitesi Sosyal Bilimler Enstitüsü Dergisi, 9(17), 195-206.

Balta, E. E. (2019). Çocuk edebiyatı üzerine yapılmış lisansüstü çalışmaların içerik analizi (2011-2018 yılları). OPUS-Uluslararası Toplum Araştırmaları Dergisi, 10(17), 464-489.

Baş, B. (2010). Söz varlığının oluşumu ve gelişiminde çocuk edebiyatının rolü. TÜBAR-XXVII, 137-159. 
Bayazıt, Z. (2011). Çocuk edebiyatı alanında yapılan lisansüstü tezlerin incelenmesi. 3. Ulusal Çocuk ve Gençlik Edebiyatı Sempozyumu (5-7 Ekim 2011). Ankara Üniversitesi, Ankara.

Beşer, R. (2019). Resimli çocuk kitaplarının zorbalık olgusu açısından doküman analizi ile incelenmesi. Yüksek Lisans Tezi. Bursa Uludağ Üniversitesi, Bursa.

Biros, Y. (2019). Çeviri çocuk kitaplarındaki değerler eğitimi üzerine bir araştırma. (Yayımlanmamış Yüksek Lisans Tezi). İstanbul Aydın Üniversitesi, İstanbul.

Cengiz, Ş. (2016). 3-6 Yaş çocuklarına yönelik hazırlanan hikâye ve masal kitaplarmdaki değerlerin incelenmesi. (Yayımlanmamış Yüksek Lisans Tezi). Uşak Üniversitesi, Ușak.

Cesur, E. (2015). Mavisel Yener'in çocuklara yönelik öykülerindeki eğitsel iletiler üzerine bir araştırma. (Yayımlanmamış Yüksek Lisans Tezi). İstanbul Aydın Üniversitesi, İstanbul.

Çalık, M. ve Sözbilir, M. (2014). İçerik analizinin parametreleri. Ĕ̆gitim ve Bilim, 39(174), 33-38.

Çer, E. (2016. 0-6 Yaş çocuk kitaplarında çocuk gerçekliği ve çocuğa görelik. Ankara: Eğiten Kitap Yayıncllık.

Çer, E. (2019). Çocuk edebiyatı yapıtlarının çocuğa göre olmasını sağlayan başat bir değişken: Eğitsel özellikler. Uluslararası Çocuk Edebiyatı ve Eğitim Araştırmaları Dergisi 3(1),1-11.

Çiftçi, F. (2013). Çocuk edebiyatında yaş gruplarına göre kitaplar ve özellikleri. Muş Alparslan Ünïversitesi" Sosyal Bilïmler Dergisi, 1(1), 125-138.

Demircan, C. (2008). Çocuk edebiyatına yönelik bir bibliyografya denemesi. Pamukkale Üniversitesi Sosyal Bilimler Enstitüsü Dergisi, 1, 165-187.

Dinçer, S. (2018). Content analysis in for educational science research: Metaanalysis, meta-synthesis, and descriptive content analysis. Bartın University Journal of Faculty of Education, 7(1), 176-190.

Doğan, Y. (2019). Seza Kutlar Aksoy'un çocuk kitaplarında özüne duyarlılk. Yüksek Lisans Tezi. Gaziantep Üniversitesi, Gaziantep.

Dönmezler, E. (2019). Türkiye'de yayınlanmış 5-8 yaş resimli çocuk kitaplarmın biçim, resim ve içerik açısından incelenmesi. (Yüksek Lisans Tezi). Mersin Üniversitesi, Mersin.

Düzenli, E. (2019). Hidayet Karakuş'un hikâyelerinin çocuk edebiyatının temel unsurları bakımından incelenmesi. (Yüksek Lisans Tezi). Bayburt Üniversitesi Bayburt. 
Ekici, M. (2019). Çocuk kitaplarında engelliler ve sorunlarının incelenmesi. (Yüksek Lisans Tezi). Gazi Üniversitesi, Ankara.

Erışık, K. (2019). Çocuk edebiyatı yazarı hasan kallimci'nin ilkokul düzeyindeki kitaplarının değerler eğitimi açısından incelenmesi. Yüksek Lisans Tezi. Ağrı İbrahim Çeçen Üniversitesi, Ağrı.

Ertekin, E. ve Bozkurt, B. Ü. (2020). Türkçe dersi öğretim programlarını değerlendirmeye yönelik araştırma bulgularının incelenmesi: Bir meta-sentez çalışması. Dil Ĕ̆itimi ve Araştırmaları Dergisi, 6(2), 613-634.

Gündeşli, P.(2017). İlkokullarda öğrencilere önerilen gülten dayıŏ̆lu hikâye kitaplarının hikâye haritası elementleri ile değerlendirilmesi. Yüksek Lisans Tezi. Çukurova Üniversitesi, Adana.

Gürbüz, Y. R. (2019). Ulviye Alpay'ın çocuk kitaplarında yer alan eğitsel iletiler. Yüksek Lisans Tezi. Bayburt Üniversitesi, Bayburt.

Işık, M. (2017). Karakter eğitimi açısından mevlâna idris zengin'in hikâye ve masallarnda eğitsel iletiler. (Yüksek Lisans Tezi). Recep Tayyip Erdoğan Üniversitesi, Rize.

İbaçoğlu, T. (2019). İlkokul öğrencilerine yönelik çocuk kitaplarının iç ve dış yapısal özellikler açısından incelenmesi. (Yüksek Lisans Tezi). Çanakkale Onsekiz Mart Üniversitesi, Çanakkale.

Karagül, S. (2019). Çocuk edebiyatının temel işlevleri: Felski'nin yaklaşımı doğrultusunda bir değerlendirme. Dil Eğitimi ve Araştırmaları Dergisi, 5(2), 334-351.

Köklücan, D. (2019). Anaokulu öğrencilerinin ulusal ve çeviri çocuk kitaplarımı tercihlerini etkileyen faktörlerin belirlenmesi. (Yüksek Lisans Tezi). Bursa Uludağ Üniversitesi, Bursa.

Kubal, S. A. (2019). Çok okunan çocuk kitaplarmın değerler yönüyle incelenmesi. (Yüksek Lisans Tezi). Gazi Üniversitesi, Ankara.

Küçük, S. (2019). Çocuk kitaplarının temel değerler bakımından incelenmesi. (Yüksek Lisans Tezi). Gazi Üniversitesi, Ankara.

Merdane, F. (2019). Illkokul 2. sınıf türkçe ders kitabındaki metinlerin çocuk edebiyatı metinlerinin nitelikleri açısından incelenmesi. (Yüksek Lisans Tezi). Necmettin Erbakan Üniversitesi, Konya.

Miles, B. M. and Huberman, A. M. (1994). Qualitative data analysis. London: SagePub.

Oğuzkan, A. F. (1983). Yerli ve yabancı yazarlardan örneklerle çocuk edebiyatı. Ankara: Emel Matbaacilı. 
Polat, S. ve Ay, O. (2016). Meta-sentez: Kavramsal bir çözümleme. Eğitimde Nitel Araştırmalar Dergisi, 4(1), 52-64.

Sever, S. (2006). Çocuk edebiyatı öğretimi nasıl olmalıdır? 2. Ulusal Çocuk ve Gençlik Edebiyatı Sempozyumu, http://cgsempoz.education.ankara.edu.tr/SBK.pdf, 04-06 Ekim, Ankara.

Okumuş, A. (2017). Bir çocuk edebiyatı yazarı olarak aydoğan yavaşlı'nın hayatı, eserleri ve eserlerinde ilettiği değgerler üzerine incelemeler. (Yüksek Lisans Tezi). Atatürk Üniversitesi, Erzurum.

Özaslan, P. (2012). Muzaffer İzgü'nün çocuklara yönelik hikâye ve romanlarındaki eğitsel iletiler. (Yüksek Lisans Tezi). Mehmet Akif Ersoy Üniversitesi, Burdur.

Palaz, F. S. (2019). Çocuk edebiyatı açısından birsen ekim özen'in eserleri ve eserlerinde yansıttı̆̆ı değgerler üzerinde incelemeler. (Yüksek Lisans Tezi). Atatürk Üniversitesi, Erzurum.

Sever, S. (2012). Çocuk ve edebiyat. İzmir: Tudem Yayınevi.

Sevim, O. (2020). Çocuk edebiyatıyla ilgili lisansüstü çalışmalardaki eğilimler: Bir içerik analizi. Türkiye Ĕ̆itim Dergisi, 5(1), 124-144.

Şahin, Ç. ve Toprak, E. (2021). İlkokul düzeyinde çocuk edebiyatına ilişkin yapılan lisansüstü çalışmaların incelenmesi. Ana Dili Ĕ̆itimi Dergisi, 9(1), 225-241.

Şirin, M. R. (2016). Çocuk, çocukluk ve çocuk edebiyatı. İstanbul: Kapı Yayınları.

Şirin, M. R. (2016). Edebiyat ve çocuk edebiyatı, edebiyatın amacı ve işlevi. Türk Dili Dergisi, CX(780), 12-31.

Tahirova, K. (2019). Abdulla Şaik'in eserlerinin değerler eğitimi açısından incelenmesi. (Yüksek Lisans Tezi). Necmettin Erbakan Üniversitesi, Konya.

Tavuş, Z. G. (2015). Gülten Dayıoğlu'nun hikâyelerinin değerler eğitimi açısından incelenmesi. (Yüksek Lisans Tezi). Necmettin Erbakan Üniversitesi, Konya.

Temur, M. (2018). Çocuk edebiyatında göç ve göçmenlik olgusu. (Yüksek Lisans Tezi). Gazi Üniversitesi, Ankara.

Temizyürek, F. (2003). Türkçe öğretiminde çocuk edebiyatının önemi. Türklük Bilimi Araştırmaları, 13, 161-167.

Tiryaki E. N. (2016). Çocuk edebiyatı alanındaki tezlerin okuma yazma kültürü açısından değerlendirilmesi. 3. Uluslararası Çocuk ve Gençlik Edebiyatı Sempozyumu (21-22 Ekim 2016), İstanbul.

Topbaş, A. (2015). Sema Maraşlı'nın masallarının değerler eğitimi açısından incelenmesi. (Yüksek Lisans Tezi). Necmettin Erbakan Üniversitesi, Konya. 
Turan, L. (2005). Arkadaş edinme güçlüğü çeken çocukların problemlerini çözmede çocuk edebiyatından yararlanma. Atatürk Üniversitesi Kazım Karabekir Ĕ̆itim Fakültesi Dergisi, 12, 124-135.

Turan, R. C. (2018). Okul öncesi öğretmenlerinin resimli çocuk kitaplarına ilişkin görüşleri. (Yüksek Lisans Tezi). Gaziantep Üniversitesi, Gaziantep.

Turan, L. ve Gerez Taşgın, F. (2018). Çocuk edebiyatında "şiddet dili" farkındalık ölçeği: Geçerlik ve güvenirlik çalışması. RumeliDE Dil ve Edebiyat Araştırmaları Dergisi, 12, 232-248.

Tursun, G. (2019). Serpil Ural'ın çocuk kitaplarının değerler eğitimi açısından incelenmesi. (Yüksek Lisans Tezi). Bayburt Üniversitesi, Bayburt.

Yalçın, A. ve Aytaş, G. (2005). Çocuk edebiyatı. Ankara: Akçağ Yayınları.

Yardimciel, F. (2015). Bir çocuk edebiyatı yazarı olarak aysel gürmen' in eserleri üzerinde ilettiği değerler bakımından incelemeler. (Yüksek Lisans Tezi). Atatürk Üniversitesi, Erzurum.

Yazıcı, N. (2013). Çocuk edebiyatı alanında üniversitelerde yapılan lisans sonrası çalışmalar. Hacettepe Üniversitesi Ĕ̆itim Fakültesi Dergisi, 28(1), 441452.

Yıldırım, A. ve Şimşek, H. (2018). Nitel araştırma yöntemleri. Ankara: Seçkin Yayınevi.

Yılmaz, Ş. Ö. (2019). Sinıf öğretmenlerinin çocuk kitaplarının disiplinler arası öğretimde kullanımı konusunda görüşlerinin incelenmesi. (Yüksek Lisans Tezi). Giresun Üniversitesi, Giresun.

Zor, E. R. G. (2015). Çok okunan Türk ve dünya çocuk klasiklerinin çeşitli değişkenler açısından incelenmesi. (Yüksek Lisans Tezi). Gazi Üniversitesi, Ankara.

\section{Kaynakça Bilgisi / Citation Information}

Kodan, H. ve Kara, K. (2021). Sınıf Eğitimi Bilim Dalı'nda çocuk edebiyatı konulu lisansüstü çalışmalara genel bakış: Bir meta-sentez çalışması. OPUS- Uluslararası Toplum Araştırmaları Dergisi, 18(Eğitim Bilimleri Özel Sayıs1), 4539-4567. DOI: 10.26466/opus.888446. 